\title{
Responses of Mammary Blood Flow and Milk Secretion to Bovine Somatotropin Infusion in Lactating Ewes
}

\author{
Akinori OSHIBE*, Jim M GOODEN \\ and Peter C WYNN \\ Department of Animal Science, University of Sydney, \\ Camden NSW 2570, Australia \\ * National Grassland Research Institute, Nishinasuno-machi, \\ Tochigi-ken 329-27
}

(Received August 21, 1995)

\begin{abstract}
Lactating ewes were fitted transit-time ultrasonic blood flow probes around the pudendal arteries. Mammary blood flow was measured continuously for 168 hours (from 6:00 $\mathrm{h}$ on Day 1 of the experiment to $6: 00 \mathrm{~h}$ on Day 8) at 5 minute intervals. Saline was infused for 26 hours (from 8:00 h on Day 1 to $10: 00 \mathrm{~h}$ on Day 2) via the right jugular vein of each ewe at the rate of $11.3 \mathrm{ml} / \mathrm{h}$, via the same catheter recombinant bovine somatotropin ( $\mathrm{rbST}$ ) was then infused for 104 hours (from $10: 00 \mathrm{~h}$ on Day 2 to $18: 00 \mathrm{~h}$ on Day 6) at $20 \mathrm{nmol} / \mathrm{h}$. Plasma growth hormone (GH) concentration increased immediately after commencement of rbST infusion, whereas no significant change in plasma insulin-like growth factor I (IGF-I) concentration was observed on Day 2. From Day 3, the plasma IGF-I concentration was significantly higher than pre-infusion values and remained the elevated lcvel after the cessation of the rbST infusion (Day 7). The yield of milk produced during the night time (the 13 hours between $17: 00 \mathrm{~h}$ and $6: 00 \mathrm{~h}$ ) was significantly greater than the pre-infusion value between Day 3 and Day 6. Mammary blood flow was greater than the pre-intusion value from the night time of Day 4 to the day time (the 11 hours between $6: 00 \mathrm{~h}$ and $17: 00 \mathrm{~h}$ ) of Day 7 . The results suggest that an increase in mammary blood flow is likely to be consequence rather than the cause of increased mammary activity with the consequent raised plasma IGF-I levels during rbST administration.
\end{abstract}

Anim. Sci. Technol. (Jpn.) 66 (12) : 1002-1006, 1995

Key words : somatotropin, IGF-I, mammary blood flow, sheep

The Galactopoietic effect of administered bovine somatotropin (bST) in dairy ruminants is well established and, furthermore, there are a number of reports showing that the uptake of metabolites through mammary tissue is enhanced by $\mathrm{bST} \mathrm{T}^{4,5,10)}$. The increase in mammary uptake of some of metabolites is thought to be accounted for solely by an increase in mammary blood flow ${ }^{4,5}$. Indeed a number of studies have demonstrated an increase in mammary blood flow by bST treatment ${ }^{4,11)}$. How- ever, it has not been elucidated whether the increase in mammary blood flow is the cause or consequence of the increase in mammary activity. The purpose of this study is to clarify whether the increase in blood flow following rbST treatment is the cause or consequence of the increased mammary activity.

\section{Materials and Methods}

The threc Border-Leicester-Merino ewes, approximately three months after parturition,

\footnotetext{
* Present address : Japan International Research Center for Agricultural Sciences, Tsukuba-shi 305
} 
without obvious abnormalities of the mammary glands, were kept in metabolic cages. Lucerne chaff $(1.3 \mathrm{~kg})$ and barley $(0.8 \mathrm{~kg})$ were fed once daily at $16: 00 \mathrm{~h}$. Polyvinyl chloride catheters (1.5 mm O.D.) were inserted into both external jugular veins. Ewes were milked at $6: 00 \mathrm{~h}$ and $17: 00 \mathrm{~h}$ using a machine following oxytocin injection (1IU i.v.). A transit time ultrasonic blood flow probe (Transonic Systems Inc.) was surgically fitted around the left pudendal artery of the each ewe ${ }^{6)}$. Mammary blood flow was measured continuously for 168 hours $(6: 00 \mathrm{~h}$ on Day 1 of the experiment to 6 : $00 \mathrm{~h}$ on Day 8) at 5 minutes intervals. Ewes were infused with sterile saline for 26 hours (8: $00 \mathrm{~h}$ on Day 1 to $10: 00 \mathrm{~h}$ Day 2) via catheter in the right jugular vein at the rate of $11.3 \mathrm{ml} / \mathrm{h}$ using peristaltic pumps. Recombinant bovine somatotropin (rbST) (recombinant bovine somatotropin : Elanco Pty. Ltd.) was dissolved in sterile saline adjusted to $\mathrm{pH} 10$ with $3 \mathrm{M}$ $\mathrm{NaOH}$ and infused for 104 hours $(10: 00 \mathrm{~h}$ on Day 2 to $18: 00 \mathrm{~h}$ on Day 6 ) at the rate of 20 $\mathrm{nmol} / \mathrm{h}$ via the right jugular vein catheter. Blood samples were collected from the left side catheter at every half hour between $8: 00 \mathrm{~h}$ to 14:00 h from Day 1 to Day 6. Blood samples on Day 7 were collected at every half hour between $8: 00 \mathrm{~h}$ to $10: 00 \mathrm{~h}$. The plasma $\mathrm{GH}$ concentration was measured each sample by radioimmunoassay ${ }^{9)}$. Pooled samples of plasma were made for each day except Day 2 for the determination of the concentration of IGF-I, by mixing equal volumes of the half hourly samples. Pooled plasma samples for Day 2 were made by mixing the half hourly samples taken every two hours (a total of 3 pooled plasma samples). Plasma IGF-I concentrations were also measured by radioimmunoassay ${ }^{\text {?). }}$.

Student's $\mathrm{t}$-test was used to examine the difference in plasma $\mathrm{GH}$ concentration between the mean value before the commencement of the rbST infusion $(8: 00 \mathrm{~h}$ to $14: 00 \mathrm{~h}$ on Day 1) and at each time point after the infusion had begun. Paired t-test was used to test the significance of the difference in plasma IGF-I concentration between the mean of the Day 1 values and at each time point during the rbST infusion. Day time (11 hours from $6: 00 \mathrm{~h}$ to $17: 00 \mathrm{~h}$ ) and night time (13 hours from $17: 00 \mathrm{~h}$ and $6: 00 \mathrm{~h}$ ) mammary blood flow were calculated by integrating the area under the profile of values measured at 5 minute intervals. The day time and night time milk yields correspond with the duration of the day time and night time mammary blood flow. Paired t-test were also used to examine the differences in day time and night time mammary blood flow and milk yield between the day before the commencement of the rbST infusion (Day 1) and the days during the infusion.

\section{Results}

Plasma GH concentration was elevated immediately after the start of the rbST infusion. The values were higher $(\mathrm{P}<0.05)$ than the pre-infusion values and were sustained during the infusion of rbST. Plasma GH concentration returned to pre-infusion levels after the cessation of the infusion (Day 7). Whereas no significant change in plasma IGF-I was observed on Day 2. Thereafter, the plasma IGFI concentration increased significantly and remained higher $(\mathrm{P}<0.01)$ than pre-infusion values after the cessation of the infusion (Day 7) (Fig. 1).

Compared with the pre-infusion values, a significant increase in mammary blood flow occurred from the night time of Day 4 to the day time of Day 7 (Fig. 2). Night time mammary blood flows tended to be higher than those of the day time in all days except Day 7 . Night time milk yield also tended to be higher than that of day time in all days except Day 7. No significant change in day time milk yield was observed, however, night time milk yield increased $(\mathrm{P}<0.05)$ from Day 3 to Day 6 (Fig. 3). 




Fig. 1. Responses of plasma GH and IGF-I concentrations to intravenous rbST infusion at the rate of $20 \mathrm{nmol} / \mathrm{h}$.

The bar indicates the period of infusion. Each symbol represents the mean plasma GH concentration of 3 ewes. Closed black symbols (A) indicate difference $(\mathrm{P}<0.05)$ from the mean value before the commencement of the infusion (Student's t-test). Each column represents the mean plasma IGF-I concentration for 3 ewes. Asterisks indicate significant difference $(P<0.05)$ from the mean of before the commencement of the infusion (Student's t-test).

\section{Discussion}

Several reports have shown that GH does not enhance lactation through a direct effect on the udder $^{3,8,9,12)}$. Indeed, the increase in milk yield was delayed by one day following elevated plasma GH levels, which occurred immediately following the start of the rbST infusion in the present experiment. Whilst the mechanism has not been completely elucidated, IGF-I is thought to be one of the hormones that are involved in the stimulation of mammary gland milk secretion by bST treatment ${ }^{1,2)}$. In this study, the increase in milk yield corresponded with an elevation in plasma IGF-I concentration. Some reports demonstrate the existence of receptors for IGF-I on capillary and large blood vessels in mammary tissue, both in vitro and in vivo ${ }^{5,14}$. However, up to

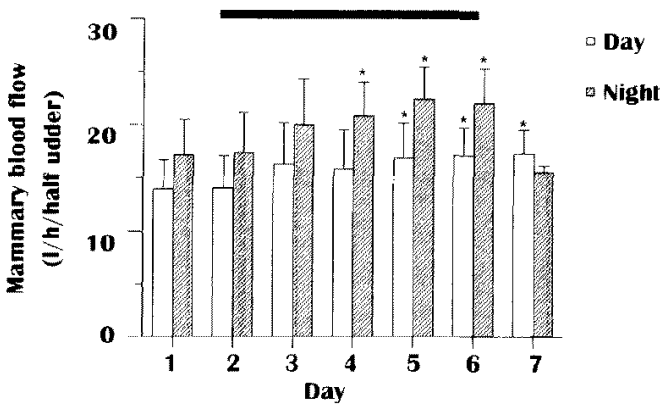

Fig. 2. Responses of mammary blood flow to intravenous rbST infusion at the rate of $20 \mathrm{nmol} /$ h.

Open columns represent the mean day time (11 hours between $6: 00 \mathrm{~h}$ to $17: 00 \mathrm{~h}$ ) mammary blood flow of 3 ewes calculated by integrating the area under the curve measured at 5 minute intervals. Hatched columns represent the mean night time (13 hours between $17: 00 \mathrm{~h}$ and $6: 00 \mathrm{~h}$ ) mammary blood flow. Vertical bars indicate the SE. The horizontal bar indicates the period of infusion. Asterisks indicate significant difference $(P<0.05)$ from the mean before the commencement of the infusion (Paired $t$-test).

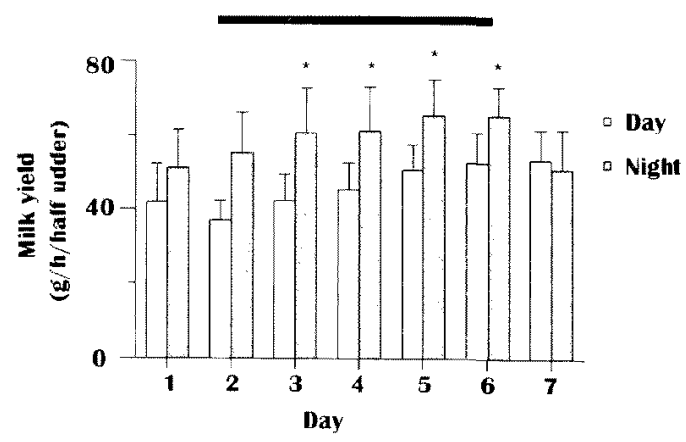

Fig. 3. Responses of milk yield to intravenous rbST infusion at the rate of $20 \mathrm{nmol} / \mathrm{h}$.

Open columns represent the mean day time (11 hours between $6: 00 \mathrm{~h}$ to $17: 00 \mathrm{~h}$ ) milk yields of 3 ewes. Hatched columns represent the mean night time (13 hours between $17: 00 \mathrm{~h}$ and $6: 00 \mathrm{~h}$ ) milk yields. Vertical bars indicate the SE. The horizontal bar indicates the period of infusion. Asterisks indicate significant difference $(P<0.05)$ from the mean before the commencement of the infusion (Paired $t$-test). 
now there has been no evidence to support the suggesting the receptors that regulate mammary blood flow during bST treatment. In this study, the increase in milk yield preceded the increase in mammary blood flow. It is likely that the physical changes of the mammary blood vessels occurred following the stimulation of mammary milk secretion by IGF-I.

The results of the present experiment suggest that increases in mammary blood flow

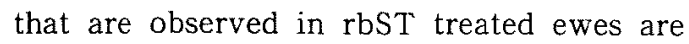
likely to be the consequence of rather than cause of the increase in mammary activity by indirect effect of the rbST infusion.

\section{References}

1) Baumrucker $C R$. Insulin-like growth factor $I$ (IGF-I) and insulin stimulate DNA synthesis and milk production in vitro with lactating bovine mammary tissue. Proc. Endocr. Soc., 561. 1986.

2) Davis SR, Gluckman PD, Hart IC, Henderson HV. Effects of injecting growth hormone or thyroxin on milk productions of insulin-like growth factor I and II in dairy cows. J. Endocr., $114: 17-24.1987$.

3) Davis SR, Hodgkinson SC, Gluckman PD, Moore LG, Breier BH. The mechanism of action of growth hormone on milk production. Proc. N.Z. Soc. Anim. Product., 48 : 191-194. 1988.

4) Davis SR, Collier RJ, McNamara JP, Head HH, Croom WJ, Wilcox CJ. Effect of thyroxin and growth hormone treatment of dairy cows mammary uptake of glucose, oxygen and other milk fat precursors. J. Anim. Sci., $66: 80-$ 89. 1988.

5) Glimm DR, Baracos VE, Kennely JJ. Effect of bovine somatotropin on immunoreactive in sulin-like growth factor-I in lactating bovine mammary tissue. J. Dairy Sci., $71: 2923-2935$.
1988.

6) Gooden JM, Giles LR. A new procedure for the continuous measurement of energy expenditure in pig and sheep. Proc. Nutr. Soc. Aust., 16: 182-189. 1991.

7) Hall DG, Holst PJ, Shutt DA. The effect of nutrition supplements in late pregnancy on ewe colostrum production plasma progesterone and IGF-1 concentrations. Aust. J. Agric. Res., 43 : 325-337. 1992.

8) McDowell GH, Hart IC. Responses to infusion of growth hormone into the mammary arteries of lactation sheep. Can. J. Anim. Sci., 64 : 306307. 1984.

9) McDowell GH, Hart IC, Kirby AC. Local intra-arterial infusion of growth hormone into the mammary glands of sheep and goats : Effects on milk yield and composition, plasma hormones and metabolites. Aust. J. Biol. Sci., $40: 181-189.1987$.

10) McDowell GH, Gooden JM, Leenanuruska D, Jois M, English AW. Effects of exogenous growth hormone on milk production and nutrition uptake by muscle and mammary tissues of dairy cows in mid-lactation. Aust. J. Biol. Sci., 40 : 295-305. 1987.

11) Mepham $T B$, Lawrence $S E$, Peters AR, Hart IC. Effects of exogenous growth hormone on mammary function in lactating goats. Horm. Metabol. Res., $16: 248-253,1984$.

12) Prosser CG, Fleet IR, Corps AN, Froesch ER, Heap RB. Increased milk secretion and mammary blood flow by intra-arterial infusion of insulin like growth factor I in to the mammary grand of the goat. J. Endocr., 126:437-443. 1990.

13) Robert RB, Boes M. Distinct receptors for IGFI. IGF-II, and insulin are present on bovine capillary endothelial cell and large vessel endothelial cells. Biochem. Biophys. Res. Comm., 124 : 203-207. 1984. 


\title{
泌乳ヒッジにおけるウシソマトトロピン注入に対する 乳腺血流量と泌乳反応
}

\author{
押部明徳*·Jim M GOODEN • Peter C WYNN \\ Department of Animal Science, University of Sydney, \\ Camden NSW 2570, Australia \\ *農林水産省草地試験場, 杤木県西那須野町 329-27
}

\begin{abstract}
泌乳ヒツジの外腸骨動脈周困に Transit-time 超音波血流量計を装着し，5 分問隔で 168 時間（試験第 1 日の午前 6 時から第 8 日の午前 6 時）の乳腺血流量を測定した．右側䅡静脈カデーテルから生理食塩 水を $11.3 \mathrm{~m} l / \mathrm{h}$ の速度で 26 時間（第 1 日の午前 8 時から第 2 日の午前 10 時）注入し，その後 recombinant ウシソマトトロピン (rbST) を $20 \mathrm{nmol} / \mathrm{h}$ の速度で 104 時間（第 2 日午前 10 時から第 6 日午後 6 時）注入した．血漿成長ホルモン $(\mathrm{GH})$ 浀度は，rbST 投与開始直後から上昇したが，第 2 日

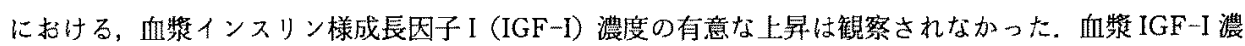
度は，第 3 日から rbST 注入開始前に比べて有意に上昇し，注入終了後まで高い漲度が維持された。第 3 日から第 6 日までの夜間 (午後 5 時加ら翌日午前 6 時までの 13 時間) 乳生産量は rbST 注入開始前に比 べて有意に高かった．第 4 日の夜問から第 7 日までの昼間（午前 6 時から午後 5 時までの 11 時間）乳腺 血流量は, rbST 注入開始前に比べて有意に高かった。これらの結果は，乳腺血流量の增加は rbST 投与 によって上昇した IGF-Iによる乳腺の活性化の原因ではなく，結果である可能性を示唆している.
\end{abstract}

日畜会報，66 (12)：1002-1006, 1995

\footnotetext{
*現所属 : 農林水産省国際農林水産業研究センター,つくば市 305
} 